\title{
PENGEMBANGAN MEDIA PEMBELAJARAN BAHASA INGGRIS DI MADRASAH ALIYAH ANNURIYAH JEMBER
}

\author{
Enik Rukiati1) Nila Susanti2) \\ 1) 2) Jurusan Bahasa Komunikasi dan Pariwisata Politeknik Negeri Jember
}

\begin{abstract}
ABSTRAK
Media pembelajaran merupakan satu hal yang sangat penting dalam proses pembelajaran. Penggunaan media pembelajaran yang tepat mampu membawa pesanpesan atau informasi yang bertujuan instruksional atau mengandung unsur-unsur pendidikan untuk mencapai tujuan pembelajaran dengan baik. Ketidakhadiran media pembelajaran dalam pembelajaran bahasa Inggris akan menyebabkan pencapaian tujuan kegiatan pembelajaran tidak tercapai secara maksimal. Kegiatan pengabdian ini bertujuan untuk membuat media pembelajaran yang berupa materi pembelajaran bahasa Inggris yang di khususkan untuk meningkatkan keterampilan berbicara menggunakan metode jigsaw. Materi pembelajaran yang disusun sangat diperlukan untuk mengatasi permasalahan yang dihadapi mitra saat ini yaitu rendahnya kemampuan berbicara peserta didik yang ada di lokasi mitra. Metode pelaksanaan kegiatan dikelompokkan menjadi tiga tahapan yaitu tahap persiapan, pelaksanaan kegiatan dan tahap evaluasi. Materi pembelajaran disusun didasarkan pada standar isi, kebutuhan dan keinginan siswa serta kondisi peserta didik dan sekolah. Pembuatan materi pembelajaran dilakukan dengan mengadopsi dan memodifikasi materi-materi yang berasal dari beberapa media cetak dan internat. Hasil dari kegiatan ini adalah tersusunnya satu buku bahan ajar yang berisi kegiatan-kegiatan pembelajaran yang dapat dipakai oleh guru sebagai materi tambahan (supplementary materials) untuk mencapai tujuan pembelajaran keterampilan berbicara (speaking).
\end{abstract}

Kata Kunci: bahasa Inggris, media, pengembangan

\section{PENDAHULUAN}

\subsection{Analisis Situasi}

Pendidikan merupakan suatu kebutuhan mendasar bagi pembangunan bangsa. Penyelenggaraan pendidikan melibatkan perencanaan pembelajaran yang matang, tenaga pendidik, peserta didik serta kurikulum yang sesuai dengan kebutuhan dan perkembangan. Kegiatan pembelajaran akan berlangsung dengan baik apabila terjadi komunikasi antara guru sebagai pendidik dan siswa sebagai peserta didik dalam menyelesaikan kegiatankegiatan pembelajaran. Dalam menyelenggarakan pendidikan, guru merencanakan kegiatan pengajarannya secara sistematis dan berpedoman pada seperangkat aturan dan rencana tentang pendidikan yang dikemas dalam bentuk kurikulum. Untuk menciptakan pembelajaran yang menarik, guru dituntut untuk menggunakan media pembelajaran yang dapat memotivasi peserta didik untuk belajar dengan metode pembelajaran yang sesuai dengan tujuan pembelajaran yang telah ditetapkan.

Tercapainya tujuan pembelajaran ditentukan oleh media pembelajaran dan metode pembelajaran. Media pembelajaran adalah alat untuk menyampaikan pesan dari guru ke siswa. Media mempunyai peran untuk mendukung efektivitas proses belajar mengajar (Suyanto, 2007). Media pembelajaran mempunyai beberapa istilah di antaranya adalah alat pandang dengar, materi pembelajaran (instructional material), komunikasi pandang dengar (audio visual Communications), pendidikan alat peraga pandang (visual Education), teknologi pendidikan (Educational 
Technology), alat peraga dan alat penjelas (Arsyad, 2007). Dalam sebuah proses pembelajaran, media pembelajaran dan metode pembelajaran merupakan dua hal yang sangat terkait satu sama lain. Oleh karena itu, materi pembelajaran (instructional material) wajib dimiliki oleh sebuah pengajaran bahasa Inggris. Hal ini karena bahasa Inggris merupakan bahasa asing bagi peserta didik. Guru dapat memanfaatkan bukubuku pengajaran yang diterbitkan oleh beberapa penerbit buku (published books) ataupun dapat mengembangkan materi pengajaran sendiri. Guru dapat mengembangkan materi pembelajaran dan aktivitas pembelajaran yang diadaptasi untuk beberapa kali mengajar. Materi yang disusun pun fleksibel yang dapat dipakai untuk mencapai tujuan pembelajaran ( Richard, 1996). Pengembangan materi oleh guru tentunya akan sangat sesuai dengan kebutuhan dan keinginan (needs and wants) dari siswa.

Secara umum, memiliki kemampuan untuk berkomunikasi menggunakan bahasa Inggris dengan benar dan lancar merupakan tujuan bagi pembelajar bahasa Inggris. Memiliki kemampuan berkomunikasi identik dengan memiliki keterampilan berbicara (speaking). Namun kondisi pada saat ini sebagian besar peserta didik mengalami kesulitan untuk meningkatkan keterampilan berbicara mereka. Keterbatasan media, sarana dan fasilitas pembelajaran memberikan kontribusi pada kurang maksimalnya penguasaan keterampilan berbicara (speaking) siswa. Di samping itu, pengajaran bahasa Inggris yang terjadi di dunia pendidikan kita lebih berorientasi pada penyelesaian materi (curriculum-based orientation) daripada penguasaan materi pembelajaran (competencies-based-orietation).Kondisi ini menyebabkan pembelajaran kurang bermakna bagi siswa.

Madrasah Aliyyah Annuriyah Jember merupakan salah satu penyelenggara pendidikan menengah yang berbasis pendidikan agama islam, menampilkan sosok pembelajaran bahasa Inggris sebagaimana yang terjadi di sebagian besar pendidikan menengah di Indonesia. Pembelajaran bahasa Inggris yang terjadi masih berorientasi pada penyelesaian materi yang ada di kurikulum (curriculumbased orientation) daripada penguasaan siswa terhadap materi pembelajaran untuk mencapai kompetensi pembelajaran bahasa Inggris yang baik (competency-based orientation). Kegiatan pembelajaran bahasa Inggris didominasi dengan kegiatan menjawab latihan-latihan soal yang ada di buku Lembar Kerja Siswa (LKS) yang sebagian besar latihannya membahas tata bahasa (grammar). Sesekali proses pembelajaran dilakukan di laboratorium bahasa untuk melakukan kegiatan mendengarkan (listening). Kondisi yang lebih memprihatinkan adalah keterampilan berbicara (speaking) siswa sangat rendah. Guru menyatakan rendahnya kemampuan siswa sangat erat kaitannya dengan rendahnya motivasi belajar bahasa Inggris karena siswa yang sekolah di sekolah ini motivasinya adalah menghafalkan dan menguasai al-quran. Guru belum menggunakan materimateri tambahan untuk membuat siswa jauh lebih tertarik untuk belajar bahasa Inggris guna mencapai tujuan pembelajaran yang telah disusun.

\subsection{Rumusan Persoalan}

Dari analisa situasi yang dilakukan di lokasi mitra dapat disimpulkan bahwa permasalahan yang dihadapi oleh mitra adalah:

1. Pelaksanaan proses belajar bahasa Inggris memiliki banyak keterbatasan yaitu:

a. Proses belajar di kelas cenderung berorientasi pada penyelesaian materi sesuai dengan yang telah ditetapkan dalam kurikulum (curriculum-based orientation) bukan peningkatan kompetensi 
bahasa Inggris dengan cara penguasaan materi pembelajaran (competencies-based orietation).

b. Motivasi siswa untuk belajar bahasa Inggris rendah. Hal ini erat kaitannya dengan interes siswa memilih sekolah di Madrasah Aliyah adalah untuk mendalami pengetahuan agama dan penguasaan baca Al-quran. Hal ini berdampak pada keterlibatan siswa dalam kegiatan pembelajaran bahasa Inggris di kelas yang cenderung pasif.

c. Laboratorium bahasa yang ada di mitra dipergunakan untuk pembelajaran menyimak. Namun variasi kegiatan pembelajaran yang ada di laboratorium belum maksimal. Siswa menyimak lagulagu berbahasa Inggris dan mengisi latihan-latihan. pembelajaran menyimak seharusnya diintegrasikan dengan pembelajaran berbicara sehingga pembelajaran akan mencapai hasil yang maksimal.

d. Proses pembelajaran bahasa Inggris masih menggunakan metode konvensional (teachercenter) di mana guru menjadi pusat kegiatan pembelajaran di kelas. Aktivitas pembelajaran kurang memberikan ruang bagi peserta didik untuk berperan aktif terlibat dalam kegiatan pembelajaran. Siswa lebih banyak melakukan kegiatan pembelajaran bahasa Inggris dengan menjawab soal-soal di buku Lembar Kerja Siswa (LKS). Peningkatan keterampilan berbicara hanya dilakukan dengan membaca dan menghafalkan dialog dan percakapan yang ada di buku pegangan siswa.

e. Guru kurang berinovasi untuk menggunakan media dan metode pembelajaran bahasa Inggris yang tepat bagi siswa khususnya dalam meningkatkan kemampuan berbicara sehingga kelas cenderung monoton dan kurang mimbangkitkan motivasi siswa untuk berbicara bahasa Inggris.

f. Pembelajaran keterampilan berbicara (speaking) belum dilakukan secara maksimal. Guru hanya menggunakan materi yang ada di buku pegangan siswa. Hal ini sangat berpengaruh pada tingkat motivasi kemampuan siswa untuk berbicara dan melakukan komunikasi menggunakan bahasa Inggris. Hal ini sangat perlu diperhatikan karena penguasaan keterampilan berbicara sangat penting bagi siswa. kemampuan bahasa Inggris siswa akan dinilai oleh pengguna lulusan dari kemampuan siswa dalam berkomunikasi menggunakan bahasa Inggris secara aktif dan lancar.

g. Tidak adanya materi pembelajaran pendukung (supplementary materials) yang dapat digunakan dalam pembelajaran bahasa Inggris untuk membantu pencapaian tujuan pembelajaran bahasa Inggris khususnya untuk keterampilan berbicara.

\subsection{Pemecahan Masalah}

Dari beberapa permasalahan yang dihadapi mitra, maka perlu dilakukan beberapa hal untuk menemukan solusinya:

a. Pengembangan materi pembelajaran yang berfungsi sebagai materi tambahan (suplementary materials) untuk meningkatkan keterampilan berbicara (speaking) bagi peserta didik kelas XI semester gasal merupakan solusi yang tepat untuk mengatasi permasalahan rendahnya motivasi belajar bahasa Inggris serta rendahnya kemampuan berbicara bahasa Inggris siswa di lokasi mitra. Brown (1995) mendefinisikan materi pembelajaran sebagian gambaran teknis dan latihan-latihan yang direncanakan 
secara sistematik untuk kegiatankegiatan dalam kelas. Dalam perspektif yang lebih luas, Tomlinson (2001) menyatakan bahwa materi pengajaran meliputi segala sesuatu yang dapat digunakan untuk memfasilitasi proses pembelajaran di dalam kelas. Oleh karena itu, pembuatan materi tambahan untuk membantu pencapaian tujuan pembelajaran keterampilan berbicara sangat diperlukan.

b. Pemilihan metode pembelajaran harus tepat sehingga dapat menunjang penerapan materi pembelajaran dengan baik. Metode pembelajaran jigsaw speaking merupakan suatu model pembelajaran yang dapat diaplikasikan untuk meningkatkan keterlibatan dan tanggung jawab peserta didik dalam setiap kegiatan pembelajaran. Metode jigsaw speaking merupakan bentuk pembelajaran kooperatif (cooperative learning) yang mendukung pembelajaran kontekstual. Sistem pembelajaran kooperatif dapat didefinisikan sebagai sistem kerja/ belajar kelompok yang terstruktur dan memenuhi lima unsur pokok yaitu saling ketergantungan positif, tanggung jawab individual, interaksi personal, keahlian bekerja sama, dan proses kelompok.

c. Pembuatan materi pembelajaran dengan metode jigsaw yang dikembangkan dibuat berdasarkan standar isi pengajaran bahasa Inggris yang meliputi standar kompetensi dan kompetensi dasar sehingga materi pengajaran yang dikembangkan selaras dengan tujuan pembelajaran bahasa Inggris untuk kelas XI semester gasal.

d. Dalam mengimplementasikan media pembelajaran metode jigsaw, guru harus benar-benar memahami kosep penerapan metode jigsaw speaking sehingga dalam implementasinya benar-benar dapat mencapai tujuan pembelajaran keterampilan berbicara (speaking).

\section{TARGET DAN LUARAN}

\subsection{Target}

Target dari program pengabdian kepada masyarakat ini adalah tersusunnya media pembelajaran khususnya materi pembelajaran untuk meningkatkan keterampilan berbicara siswa dengan menggunakan metode jigsaw yang dikembangkan berdasarkan standar isi pengajaran bahasa Inggris kelas XI semester gasal. Materi yang dikembangkan dapat digunakan oleh guru sebagai materi penunjang (suplementary materials) untuk menambah pengalaman belajar peserta didik dalam menggunakan bahasa Inggris yang sedang dipelajarinya dalam kegiatan-kegiatan pembelajaran yang lebih bermakna sehingga tujuan pembelajaran dapat tercapai dengan lebih baik.

\subsection{Luaran}

Luaran dari kegiatan ini adalah tersusunnya sebuah buku ajar yang berisi bacaan (reading text) dan diikuti kegiatan-kegiatan pembelajaran yang memberikan peluang kepada siswa untuk memperoleh pengalaman menggunakan bahasa Inggris yang sedang dipelajarinya dalam kegiatan pembelajaran yang lebih bermakna. Melalui kegiatan-kegiatan yang ada di buku ini, semua peserta didik diharapkan akan mempunyai kemampuan berkomunikasi bahasa Inggris (communicative competence) yang baik, terbiasa berbicara menggunakan bahasa Inggris serta mempunyai rasa percaya diri, motivasi serta tanggung jawab dalam belajar .

\section{METODE PELAKSANAAN}

Pelaksanaan kegiatan pengabdian kepada masyarakat dilakukan melalui beberapa tahapan. Tahapan pelaksanaan kegiatan dibuat dan dirancang agar kegiatan program 
berjalan dengan efektif dan tepat sasaran. Tahapan kegiatan tersebut meliputi persiapan, pelaksanaan dan evaluasi program.

\subsection{Persiapan}

Tahapan awal yang dilakukan dalam pelaksanaan program adalah persiapan. Pada tahapan ini, Tahapan awal yang dilakukan dalam pelaksanaan program adalah persiapan. Pada tahapan ini, ketua pelaksana melakukan interview dengan guru kepala sekolah dan bahasa Inggris di tempat mitra. Interview dengan kepala sekolah dilakukan untuk memperoleh gambaran umum tentang kondisi lembaga mitra, kebijakan lembaga serta harapan lembaga terhadap pembelajaran bahasa Inggris. Interview dengan guru bahasa Inggris dilakukan untuk memperoleh data tentang metode pembelajaran, materi pengajaran, buku pegangan siswa dan guru serta, tingkat kemampuan bahasa Inggris (level of proficiency) dan kendala-kendala yang dihadapi guru dalam melaksanakan proses pembelajaran serta kesulitankesulitan umum yang dialami peserta didik.

\subsection{Pelaksanaan}

a. Tahap Pertama

Ketua pelaksana dibantu dengan anggota pelaksana mempelajari kurikulum pembelajaran bahasa Inggris untuk SMA/MA kelas XI. Mempelajari standar isi yang berisi standar kompetensi dan kompetensi dasar keterampilan berbicara (speaking) SMA/MA kelas XI semester gasal. Data yang diperoleh pada tahapan ini dipakai sebagai dasar dalam pemilihan materi dan fungsi-fungsi bahasa (language functions) yang dikembangkan dalam media pembelajaran yang akan disusun.

Pada tahap ini pelaksana kegiatan pengabdian juga berdiskusi untuk menentukan metode pembelajaran yang tepat yang akan dipakai untuk menyampaikan meteri yang akan disusun. Metode jigsaw dipilih sebagai metode yang dapat digunakan untuk meningkatkan keterampilan berbicara (speaking) peserta didik. Pada tahapan ini, guru dilibatkan untuk berdiskusi menentukan topik-topik yang dapat dimasukkan dalam materi pengajaran yang disusun serta memberikan masukan terkait dengan tingkat kesulitan dari teks-teks yang kita susun. Disamping itu, dalam tahapan ini guru secara langsung belajar untuk mengembangkan materi pembelajaran.

\section{b. Tahap Kedua}

Pada tahap ini tim pelaksana program mengujicobakan materi pembelajaran kepada peserta didik. Kegiatan pelatihan ini menggunakan pendekatan yang menekankan pada siswa (students-centered) yaitu menekankan kepada keterlibatan peserta didik dalam memperoleh pengalaman berbicara menggunakan bahasa Inggris (students-centered). Pada tahap ini tim pelaksana pengabdian dan guru mengamati kondisi tiap-tiap siswa, memantau apakah siswa masih mempunyai kendala dalam berbicara menggunakan bahasa Inggris, mengidentifikasi hal-hal yang masih perlu dikembangkan dalam meningkatkan keterampilan berbicara siswa serta mencari cara bagaimana siswa mampu melakukan kegiatan pembelajaran sebagaimana yang telah disusun dan direncanakan. Pendekatan students-centered ini sangat cocok untuk diterapkan dalam pelaksanaan pembelajaran peningkatan keterampilan berbicara dengan menggunakan metode Jigsaw.

\subsection{Evaluasi}

Evaluasi pelaksanaan program dilakukan oleh ketua pelaksana beserta anggota dengan mengkaji keseluruhan kegiatan pelaksanan pengabdian yang telah dilakukan. Evalusai dilakukan dengan menganalisa materi pembelajaran yang telah disusun, mengamati keterlibatan peserta didik dalam menyelesaikan kegiatan 
pembelajaran dari materi pembelajaran yang disusun serta mengidentifikasi kendala-kendala yang mungkin timbul dalam penerapan metode jigsaw sehingga ditemukan suatu rujukan yang efektif bagi guru dalam melaksanakan metode jigsaw untuk mencapai tujuan pembelajaran secara lebih efektif.

\section{HASIL DAN PEMBAHASAN}

Hasil dari kegiatan ini dapat kelompokkan menjadi tiga bagian yaitu hasil dari interview, pelaksanaan dan evaluasi.

\subsection{Hasil Interview}

Dari interview yang dilakukan kepada kepala sekolah diperoleh informasi bahwa Madrasah Aliyah Annurriyah Jember adalah yayasan pendidikan yang didirikan pada tahun 1984. Motivasi pendirian MA. Annuriyyah adalah karena permintaan masyarakat setempat agar anakanak/santri lulusan MTs Annuriyyah dapat tetap melanjutkan pendidikannya dilingkungan Pondok Pesantren. MA. Annuriyyah merupakan kelas jenis kelamin sama (single sex class) yang terdiri dari tiga jenjang. Masing-masing jenjang terdiri dari dua kelas. Yayasan pendidikan ini menggunakan kurikulum Tingkat Satuan Pendidikan (KTSP).

Sedangkan dari interview yang dilakukan terhadap guru bahasa Inggris diperoleh informasi bahwa guru menggunakan materi pembelajaran yang berasal dari buku paket. Kegiatan siswa didominasi dengan penyelesaian soal-soal yang ada di Lembar Kerja siswa (LKS) untuk memenuhi target penyelesaian kurikulum dan persiapan ujian Nasional. Lebih lanjut, guru menyampaikan bahwa kemampuan siswa dalam berkomunikasi menggunakan bahasa Inggris masih rendah. Tingkat kemampuan berbahasa Inggris mereka berada pada tingkat dasar.

\subsection{Hasil Pelaksanaan Kegiatan}

Hasil dari kegiatan pengabdian kepada masyarakat ini adalah tersusunnya media pembelajaran dalam bentuk materi pengajaran (instructional materials) bahasa Inggris untuk meningkatkan keterampilan berbicara (speaking) siswa dengan menggunakan metode jigsaw. Media ini sangat cocok untuk diterapkan dalam pembelajaran bahasa Inggris untuk meningkatkan keterampilan berbicara (speaking) bagi peserta didik kelas XI di Madrasah aliyyah Annuriyyah Jember karena materi pembelajaran disusun berdasarkan standar isi pembelajaran bahasa Inggris SMA/MA kelas XI, kebutuhan dan keinginan (needs and wants) peserta didik serta kondisi peserta didik dan sekolah.

Pengembangan media pembelajaran bahasa Inggris yang dikembangkan untuk membantu proses pembelajaran bahasa Inggris di Madrasah Aliyah Annuriyah ini disusun oleh tim pelaksana kegiatan pengabdian Politeknik Negeri Jember berdasarkan analisa awal (preliminary study) yang dilakukan kepada pihak mitra untuk mengetahui kondisi pembelajaran di lokasi mitra. Dari kegiatan ini diperoleh kesimpulan bahwa mitra pengabdian membutuhkan sebuah solusi untuk meningkatkan kemampuan berbahasa Inggris siswa utamanya keterampilan berbicara (speaking) yang selama ini masih menjadi persoalan bagi guru. Mitra membutuhkan solusi agar siswa mampu meningkatkan keterampilan berbicara (speaking) mereka.

Materi pembelajaran yang disusun di khususkan untuk peserta didik kelas XI semester gasal. Buku ini terdiri dari tujuh tema yang di kembangkan berdasarkan standar isi pengajaran bahasa Inggris untuk sekolah tingkat menengah. Tema-tema dipilih untuk mencapai standar kompetensi dan kompetensi dasar dari pengajaran bahasa Inggris kelas XI semester Gasal. Standar Kompetensi dan Kompetensi Dasar untuk pembelajaran keterampilan berbicara (speaking) kelas XI semester Gasal diuraikan dalam tabel 5.I. Berdasarkan 
standar kompetensi dan kompetensi dasar, maka disusunlah tujuh materi yang disusun untuk mencapai tujuan pembelajaran keterampilan berbicara (speaking). Materi yang disusun merupakan kumpulan materi-materi yang diunduh dari internet dan disusun ulang untuk disesuaikan dengan tujuan pembelajaran yang dapat dipakai sebagai media pembelajaran. Materi dan fungsi-fungsi bahasa yang diajarkan diuraikan dalam tabel 2 .

Pengembangan media pembelajaran ini melibatkan guru bidang studi bahasa Inggris yang ada di lokasi mitra. Hal ini bertujuan agar materi yang disusun benar-benar sesuai dengan situasi dan kondisi dari siswa dan sekolah. Di samping itu, melibatkan guru dalam penyusunan media pembelajaran dalam bentuk materi ajar ini dapat memberikan suatu pengetahuan dan pengalaman bagi guru agar ke depannya guru mampu mengembangkan media pembelajaran dalam bentuk materi pengajaran sendiri yang dapat digunakan oleh guru untuk membantu siswa mencapai tujuan pembelajaran dengan baik. Setelah media pembelajaran selesai tersususun, tim pengabdian mengujicobakannya kepada siswa. Kegiatan uji coba bertujuan untuk memastikan media pembelajaran yang disusun dapat diaplikasikan secara tepat dan sesuai dengan tingkat kemampuan bahasa Inggris pesrta didik (students' proficincy level)sehingga benar-benar memberikan kontribusi positif terhadap upaya untuk meningkatkan keterampilan berbicara (speaking) siswa. Dari kegiatan ini tim menganalisa dan mengevaluasi proses kegiatan pembelajaran, peran guru, keterlibatan siswa dan juga motivasi siswa selama mengikuti proses pembelajaran.

Tabel 1. Standar Kompetensi dan Kompetensi Dasar Keterampilan Berbicara SMA/MA kelas XI semester gasal.

\begin{tabular}{|c|c|}
\hline $\begin{array}{c}\text { Standar } \\
\text { Kompetensi }\end{array}$ & Kompetensi Dasar \\
\hline $\begin{array}{l}\text { 1. Mengungkap } \\
\text { kan makna } \\
\text { dalam teks } \\
\text { percakapan } \\
\text { transaksional } \\
\text { dan } \\
\text { interpersonal } \\
\text { resmi dan } \\
\text { berlanjut } \\
\text { (sustained) } \\
\text { dalam } \\
\text { konteks } \\
\text { kehidupan } \\
\text { sehari-hari }\end{array}$ & 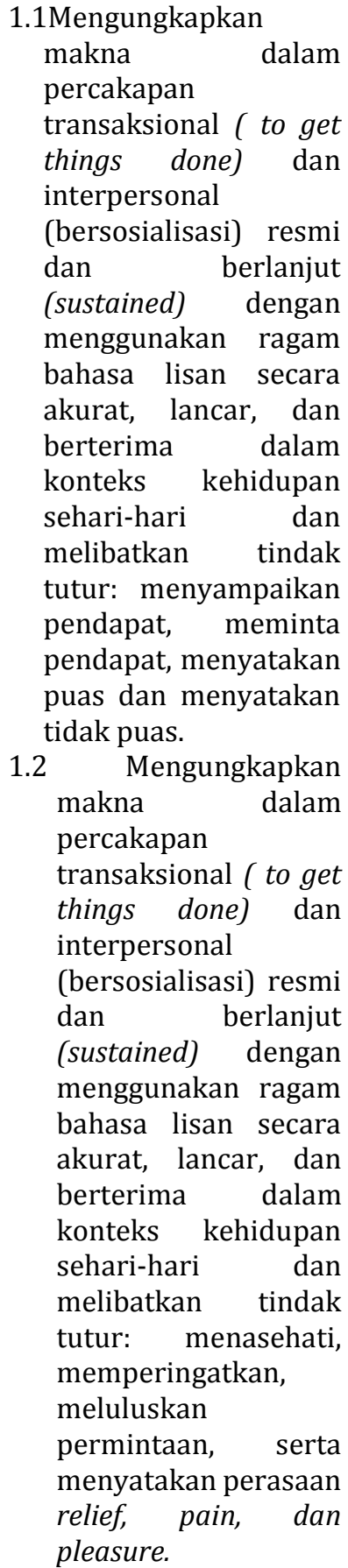 \\
\hline $\begin{array}{l}\text { 2. Mengungkap } \\
\text { kan makna } \\
\text { dalam teks } \\
\text { fungsional } \\
\text { pendek dan } \\
\text { monolog } \\
\text { yang } \\
\text { berbentuk } \\
\text { report, } \\
\text { narrative dan }\end{array}$ & $\begin{array}{l}\text { 2.1 Mengungkapkan } \\
\text { makna dalam teks } \\
\text { lisan fuctional } \\
\text { pendek resmi dan } \\
\text { tak resmi secara } \\
\text { akurat, lancar, dan } \\
\text { berterima dalam } \\
\text { berbagai konteks } \\
\text { kehidupan sehari- } \\
\text { hari. }\end{array}$ \\
\hline
\end{tabular}




\begin{tabular}{|c|c|}
\hline $\begin{array}{l}\text { analytical } \\
\text { exposition } \\
\text { dalam } \\
\text { konteks } \\
\text { kehidupan } \\
\text { sehari-hari }\end{array}$ & $\begin{array}{l}\text { 2.2 Mengungkapkan } \\
\text { makna dalam teks } \\
\text { monolog dengan } \\
\text { menggunakan } \\
\text { ragam bahasa lisan } \\
\text { secara akurat, dan } \\
\text { berterima dalam } \\
\text { konteks kehidupan } \\
\text { sehari-hari dalam } \\
\text { teks berbentuk: } \\
\text { report, narrative } \\
\text { analytical } \\
\text { exposition. }\end{array}$ \\
\hline
\end{tabular}

Tabel 2. Tema dan Fungsi-fungsi Bahasa (Language Functions).

\begin{tabular}{|l|l|l|}
\hline NO. & \multicolumn{1}{|c|}{ TEMA } & FUNGSI BAHASA \\
\hline I. & $\begin{array}{l}\text { Shopping } \\
\text { second-hand }\end{array}$ & $\begin{array}{l}\text { Expressing } \\
\text { satisfaction and } \\
\text { dissatisfaction }\end{array}$ \\
\hline 2. & Bad driver & $\begin{array}{l}\text { Prohibition and } \\
\text { waming }\end{array}$ \\
\hline 3. & $\begin{array}{l}\text { Global } \\
\text { warming }\end{array}$ & $\begin{array}{l}\text { Asking for and } \\
\text { giving opinion }\end{array}$ \\
\hline 4. & Mother's day & $\begin{array}{l}\text { Expressing pain, } \\
\text { relief and } \\
\text { pleasure }\end{array}$ \\
\hline 5. & Smoking & Giving advice \\
\hline 6. & In the hotel & Granting a reguest \\
\hline 7. & Disaster & Delivering speech \\
\hline
\end{tabular}

\subsection{Hasil Evaluasi}

Dari uji coba yang telah dilakukan, media pembelajaran bahasa Inggris model jigsaw yang dikembangkan membuat siswa menjadi lebih percaya diri dan mempunyai rasa tanggug jawab dalam kegiatan pembelajaran. Hai ini karena metode jigsaw merupakan salah satu teknik atau model pembelajaran kooperative (cooperative learning) yang sangat cocok dan efektif untuk diterapkan pada pembelajar keterampilan berbicara bahasa Inggris bagi pemula.

Pada saat kegiatan dilakukan, ada dua puluh enam siswa yang hadir. Dari jumlah yang ada di bagi menjadi lima kelompok kecil. Ada 5 kelompok yang beranggotakan 5 orang dan 1 kelompok yang terdiri dari 6 orang yang dipilih secara acak dan berkemampuan bahasa Inggris yang berbeda-beda. Peserta didik bekerja sama dan saling ketergantungan yang positif antar siswa dengan siswa yang lain dalam kelompok. Dengan keterbatasan kosakata dan keberanian untuk berbicara, siswa dikondisikan dan dituntut untuk berbicara menyampaikan hasil diskusi mereka dalam kelompok jigsaw kepada teman mereka di kelompok asal. Pelaksana kegiatan dan guru memonitor selama kegiatan berlangsung dan memberikan penghargaan serta koreksi secara lisan terhadap kesalahan pengucapan yang dilakukan siswa secara oral (oral corrective feedback). Dari kegiatan uji coba secara keseluruhan diperoleh suatu kesimpulan bahwa:

1. Perbendaharaan kata siswa masih sangat rendah. Hal ini sangat berpengaruh terhadap kelancaran siswa dalam menyampaikan pendapat.

2. Ketepatan mengucapkan kata-kata (pronounciation) masih sangat perlu ditingkatkan. Kehadiran model yang baik akan sangat membantu memperbaiki ketepanan (accuracy) berbicara siswa.

3. Siswa tidak terbiasa melakukan kegiatan pembelajaran bahasa inggrris untuk berkomunikasi sehingga mereka cenderung merasa canggung untuk berbicara bahasa Inggris.

4. Guru bahasa Inggris kurang mampu berkomunikasi dengan siswa, memberikan motivasi dan wawasan kepada siswa akan pentingnya belajar bahasa Inggris.

Dari beberapa hal yang ditemukan dalam proses pembelajaran bahasa Inggris di lokasi mitra dapatlah dikatakan bahwa materi pembelajaran bahasa Inggris untuk meningkatkan keterampilan berbicara dengan metode jigsaw ini terbukti dapat meningkatkan motivasi dan keterlibatan siswa dalam proses pembelajaran. 


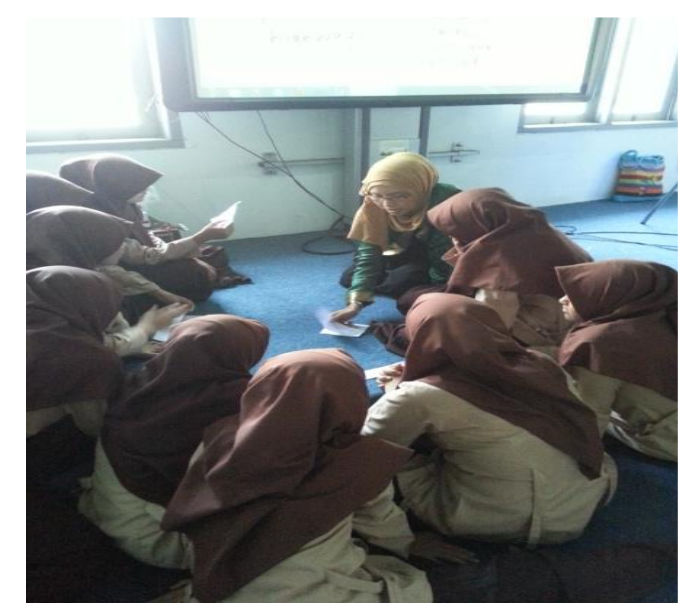

Gambar 1. Pemberian Arahan Dibagi dalam Kelompok Kecil

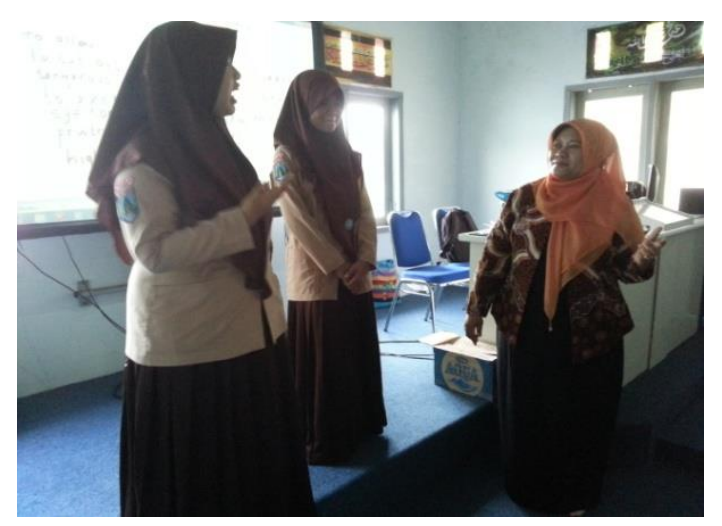

Gambar 2. Peserta Didik

Mempresentasikan Hasil Diskusi Kelompok di Depan Kelas

Secara umum, penerapan media pembelajaran bahasa Inggris menggunakan metode jigsaw untuk meningkatkan keterampilan berbicara siswa dapat dilakukan melalui beberapa langkah, yaitu:

a. Siswa dibagi menjadi beberapa kelompok kecil, setiap kelompok terdiri dari 4-6 siswa dengan kemampuan yang berbeda. Heterogenitas kemampuan siswa harus diperhatikan untuk menghindari adanya kelompok yang dominan berkemampuan baik dan ada kelompok yang beranggotakan siswa dengan kemampuan yang kurang baik semua. Kelompok ini disebut kelompok asal (kelompok Jigsaw). b. Jumlah anggota dalam kelompok asal menyesuaikan dengan jumlah bagian materi pelajaran yang akan dipelajari. Dalam teknik Jigsaw ini, setiap siswa diberi tugas mempelajari salah satu bagian materi pembelajaran tersebut. Semua siswa dengan materi pembelajaran yang sama belajar bersama dalam kelompok yang disebut kelompok ahli. Dalam kelompok ahli, siswa mendiskusikan bagian materi pembelajaran yang sama, serta menyusun rencana bagaimana menyampaikan kepada temannya jika kembali ke kelompok asal.

c. Setelah siswa berdiskusi dalam kelompok ahli maupun kelompok asal, selanjutnya dilakukan presentasi masing-masing kelompok atau dilakukan pengundian salah satu kelompok untuk menyajikan hasil diskusi kelompok yang telah dilakukan agar guru dapat menyamakan persepsi pada materi pembelajaran yang telah didiskusikan.

d. Guru memberikan penghargaan pada kelompok yang berhasil mempresentasikan hasil diskusinya dengan baik dan benar.

Langkah-langkah penerapan metode jigsaw speakingdiatas sangat efektif untuk diterapkan. Metode ini tidak hanya menarik tetapi yang lebih penting adalah metode ini melatih tanggung jawab siswa untuk mampu bekerja sama dengan siswa lain (tim) dalam menyelesaikan tugas yang diberikan.

\section{KESIMPULAN DAN SARAN}

\subsection{Kesimpulan}

Pengembangan media pembelajaran bahasa Inggris di Madrasah Aliyyah Annuriyah Jember sangat penting untuk dilakukan. Media pembelajaran yang dikembangkan sendiri akan lebih tepat untuk 
diterapkan. Hal ini karena pengembang mengetahui dengan pasti kondisi siswa dan sekolah sehingga pengembangan media pembelajaran yang dikembangkan akan didasarkan tidak saja pada kebutuhan pencapaian pembelajaran tetapi juga didasarkan pada kebutuhan siswa dan kondisi sekolah.

\subsection{Saran}

Media pembelajaran untuk meningkatkan keterampilan berbicara (speaking) siswa dengan menggunakan metode jigsaw yang telah dikembangkan oleh tim pengabdian sangat efektif untuk meningkatkan keterampilan berbicara (speaking) siswa. Ada beberapa hal yang perlu diperhatikan baik oleh pihak sekolah, guru maupun siswa agar penerapan teknik jigsaw benar-benar dapat berjalan dengan baik dan mencapai tujuan pembelajaran yang telah ditentukan.

Sekolah hendaknya memberikan fasilitas layanan internet dan buku-buku yang dapat dimanfaatkan oleh guru dalam menyiapkan materi tambahan bagi siswa. Di samping itu, sekolah juga memfasilitasi guru untuk mengikuti pertemuan ilmiah (seminar, workshop, training) yang merupakan sarana bagi guru untuk bertemu, bertukar pengalaman dan berbagi inovasi-inovasi dalam pembelajaran bahasa Inggris.

Peran guru harus lebih ditingkatkan. Peran guru sudah mengalami pergeseran yang pada mulanya hanya mengajar tapi sekarang guru juga dituntut untuk menjadi pembuat materi ( material developer). Guru harus kreatif dalam memilih, menyusun dan mendesain materi pembelajarannya sendiri dan menentukan metode pengajaran yang sesuai untuk mempermudah siswa mencapai tujuan pembelajaran yang telah ditentukan.

Dalam mengimplementasikan metode jigsaw, guru harus mengetahui kemampuan masing-masing siswa.
Heteroganitas kemampuan siswa dalam kelompok jigsaw harus benar-benar dijaga. Hal ini untuk mengantisipasi adanya kelompok yang beranggotakan siswa-siswa dengan kemampuan lebih dan ada kelompok yang beranggotakan siswa-siswa dengan kemampuan kurang. Bila hal ini terjadi maka tujuan pembelajaran tidak akan tercapai.

Ketercapaian tujuan pembelajaran sangat tergantung kepada subjek pembelajaran yaitu siswa. Siswa harus diberikan wawasan dan motivasi tentang pentingnya belajar bahasa Inggris dan pentingnya keterlibatan mereka dalam proses pembelajaran.

Dengan memperhatikan beberapa hal tersebut di atas, media pembelajaran dalam bentuk materi pembelajaran (instructional materials) yang telah dikembangkan akan membantu guru dalam meningkatkan keterampilan berbicara (speaking) siswa.

\section{DAFTAR PUSTAKA}

Brown, H.D (1995). Principles of Language Learning and Teaching. New York. Longman.

Lie, Anita. (2004). Cooperative Learning Mempraktikkan Cooperatif Learning diRuang-Ruang Kelas. Jakarta: Grasindo.

Richard, C, Jack. 1996. Teachers as Course Developers. Cambridge University Press.

Suyanto, K.K.E. 2007. English for Young Learner. Jakarta: PT. Bumi Aksara

Tomlinson, B. 2001. Material Development. In R.Carter \& D. Nunan (eds.), The Cambridge Guide to Teaching English to Speakersof Others Language (pp.66-71). Cambridge: Cambridge University Press. 20I4. Kreatif. Bahasa Inggris Kelas XI Semester Gasal. Pegangan Guru. Solo: Viva Pakasindo 